\title{
FORUM
}

\section{Suboptimal Nutrition and Feeding Behavior of Hemipterans on Less Preferred Plant Food Sources}

\author{
ANTÔNIO R. PANIZZI \\ Centro Nacional de Pesquisa de Soja, Embrapa, Caixa postal 231, \\ 86001-970, Londrina, PR.
}

An. Soc. Entomol. Brasil 29(1): 1-12 (2000)

Nutrição Subótima e Comportamento Alimentar de Hemípteros em Plantas Menos Preferidas

\begin{abstract}
RESUMO - Hemípteros (heterópteros) fitófagos são, em geral, polífagos, alimentando-se de uma ampla variedade de plantas. Dentre essas plantas, fontes nutricionais menos preferidas são também exploradas como alimento e/ou abrigo. Para ilustrar isso, o comportamento alimentar do percevejo verde Nezara viridula (L.) (Pentatomidae) em plantas menos preferidas no Norte do Paraná é discutido. Essa espécie de percevejo alimenta-se de várias plantas selvagens, não cultivadas, e de plantas cultivadas, as quais são menos preferidas. Nessas plantas o percevejo muda seu hábito alimentar, ou seja, deixa de ser um típico sugador de sementes ou frutos, passando a se alimentar de tecido vegetativo, como folhas e ramos, com conseqüências no desempenho das ninfas e dos adultos. Outros sugadores de sementes, tais como os pentatomídeos Euschistus heros (F.) e Dichelops melacanthus (Dallas) e o alidídeo Neomegalotomus parvus Westwood, também mudam seus hábitos alimentares em plantas menos preferidas, trocando as sementes por tecidos vegetativos. Esses e outros exemplos mencionados, demonstram para esse agrupamento (guilda) alimentar, que as fontes nutricionais constituídas por plantas menos preferidas desempenham um papel importante na história da vida desses insetos, e que, em geral, esse fato é subestimado.
\end{abstract}

PALAVRAS-CHAVE: Insecta, Hemiptera, Pentatomidae, plantas hospedeiras, ecologia nutricional.

ABSTRACT - Phytophagous hemipterans (heteropterans) are, in general, polyphagous, feeding on a wide array of plants. Among these, less preferred plant food sources are also explored as food and/or shelter. To illustrate this, I will discuss the feeding behavior of the southern green stink bug, Nezara viridula (L.) (Pentatomidae) on less preferred plants in Northern Paraná state. This bug feeds on several uncultivated-wild, and on cultivated plants, which are less preferred, changing its feeding behavior, from a typical seed/fruit sucking habit, to leaf/stem feeding, with consequences for its nymphal and adult performance. Other seed suckers, such as Euschistus heros (F.) and Dichelops melacanthus (Dallas) (Pentatomidae) and Neomegalotomus parvus Westwood (Alydidae), also change their feeding behavior from seeds to vegetative tissues (leaf, stems) 
when feeding on less preferred food plants. These and other mentioned examples demonstrate that for this feeding guild in particular, the less preferred food plant sources play an important role in the life history of these bugs, and that this fact is, in general, underestimated.

KEY WORDS: Insecta, Hemiptera, Pentatomidae, host plants, nutritional eco$\log$.

\section{Introduction}

The nutritional quality of plants is variable in space and in time. In order to compensate for the changes in the quality of the food, insects must adapt to explore alternate food plants, most of the time, on less preferred plants, while the most suitable and preferred hosts are unavailable.

Insects are known to have several types of compensatory responses when faced with the variability in quality of the available foods. As pointed out by Simpson \& Simpson (1990), there are three main compensatory responses: altering consumption, dietary selection, and post-ingestive compensation. In this paper I will discuss some aspects of these compensatory responses, and how hemipterans behave, with regard to feeding, and how nymphs and adults perform, on less preferred plants food sources. This paper is based on field observations and on field and laboratory studies conducted mostly with a pentatomid, the southern green stink bug, Nezara viridula (L.), a major pest of soybean [Glycine $\max (\mathrm{L}$.) Merrill] in Londrina, Northern of Paraná state (latitude $23^{\circ} 11^{\prime} \mathrm{S}$, longitude $51^{\circ} 11^{\prime} \mathrm{S}$ ), Brazil. Data from other species of hemipterans studied under similar circumstances will be touched on, as well. Finally, it should be mentioned that it is not my purpose to present an extensive review of the literature on this topic, which has been done by other authors elsewhere, but, rather, discuss a case study, i.e., $N$. viridula on less preferred food plants in Northern Paraná, to demonstrate the role of these so called "food plants" on the life history of insects.

\section{Feeding Behavior of Hemipterans}

Phytophagous hemipterans feed by inserting their stylets into plant tissues and injecting a watery saliva, which contains digestive enzymes, sucking out the liquefied food contents (Miles 1972). This "lacerate-and-flush" mode of feeding probably evolved from a rasping-sucking type of feeding (Goodchild 1966). In addition to the digestive saliva, another saliva that solidifies to form a stylet sheath is produced, which remains in plant tissues and can be used to estimate feeding frequency of these insects (Bowling 1979, 1980). The external part of the stylet sheath is actually seen and recorded; it was called 'flange' by Nault \& Gyrisco (1966), and occurs also in other plant sucking insects (aphids).

The damage to plant tissues, including seeds and fruits, results from the frequency of stylet penetration and feeding duration, associated with salivary secretions that can be toxic and cause tissue necrosis (see reviews by Slansky \& Panizzi [1987] for further details on seed-suckers feeding behaviors, and by Hori [in press] on salivary secretions and tissue damage).

\section{Polyphagy in Hemipterans}

Phytophagous hemipterans are, in general, polyphagous. However, they may show feeding preferences for certain taxa. For instance, generalist feeders such as the pentatomid $N$. viridula prefer legumes and brassicas (Todd \& Herzog 1980); another pentatomid, Edessa meditabunda (F.), prefers legumes and solana- 
ceous plants (Silva et al. 1968); and species of the genera Acrosternum and Euschistus feed preferably on legumes, while species of the genera Oebalus, Mormidea, Aelia and Eurygaster prefer to feed on graminaceous plants (Panizzi et al., in press). These and other trends make hemipterans to evolve close relationships with certain plant species. However, because preferred plants are often not available, hemipterans are forced to feed on less preferred plants, showing different feeding behavior and variable performance, and this will be discussed further on.

\section{Seeds as Main Feeding Sites}

Among the many structures of plants, seeds and immature fruits are the main feeding sites of hemipterans (Schuh \& Slater 1995). Seeds are packages of highly concentrated nutrients compared to other plant parts. Mean values of percentage content of protein and oil range between $10-30$ and 10 40 in seeds, while in leaves these values seldom reach 15 and $10 \%$, respectively (Shorland 1963, Slansky \& Scriber 1985). These characteristics make seeds preferred feeding sites, from which nutrients are more easily obtained (I do not consider here physical (hardness, small size, etc.) and chemical (toxic allelochemicals) features that may make seeds less suitable as food [see review by Slansky \& Panizzi 1987]).

When seeds are not available, seed suckers are able to obtain nutrients from other plant tissues, such as growing tips or flowers; but in general these do not allow complete nymphal development or egg production. In this case adults will fly and disperse to locate appropriate food plants at reproductive stages. Nymphs, however, will have their survivorship seriously threatened, despite their ability to disperse by walking relatively long distances (references in Slansky \& Panizzi 1987).

\section{Feeding on Stems, Branches, Leaves and Roots}

Other plant parts, besides seeds/fruits, are used as food sources. Several species of hemipterans feed preferably on stems, such as the neotropical rice bug, Tibraca limbativentris Stål, which feeds mostly on rice stems near the ground (Rizzo 1976). The pentatomid Edessa meditabunda (F.) feeds on stems of host plants, such as soybean (Galileo \& Heinrichs 1979) and on leaves of most host plants (Rizzo 1971). When feeding on soybean stems, adult E. meditabunda stay in an upside down position (Panizzi \& MachadoNeto 1992), which may better facilitate penetration of tissues by their relatively short stylets than would the normal (head-up) position; the shortness of the mouthparts may explain why this bug tends not to feed on seeds which, because they are protected by pod walls, are somewhat out of reach.

Leaf feeding has been observed in the seed sucker $N$. viridula, particularly on leaf veins of the preferred host, soybean, and on the less preferred host, castor bean, Ricinus communis L. (A.R. Panizzi, unpublished).

Several species of hemipterans feed on branches of trees, such as the pentatomids Antiteuchus mixtus (F.) and A. tripterus (F.) that feed on privet, Ligustrum lucidum Ait. (Oleaceae) (Panizzi \& Grazia, in press). These bugs are abundant on privet trees in Londrina. Attempts to raise nymphs on fruits (berries) of privet failed. Apparently, they need to feed on the branches (bark) of this tree, where they get the nutrients that allow their development. Other hemipterans, such as aradids, are specialized to feed on mycelia of higher fungi, grown under the loose bark of trees; but one species feeds on phloem, cambium and xylem tissues of pine trees (Aradus cinnamomeus Panzer) (Heliövaara, in press).

Other species of hemipterans feed on roots, such as the cydnids Scaptocoris castanea Perty and Atarsocoris brachiariae Becker, major pests of several crops and pastures (Becker 1996, Lis et al., in press), and Cyrtomenus mirabilis (Perty) pest of peanuts, Arachis hypogaea L. in Brazil (Zucchi et al. 1993). However, this feeding habit among hemipterans is restricted, probably due to the low content of nutrients in roots, in addition 
to the difficulty of access.

\section{Less Preferred Plants as Food Sources}

Most species of hemipterans spend only a third of their lifetimes feeding on spring/ summer crops, usually their preferred hosts. The rest of the time they spend feeding and breeding on alternate hosts, some of them of low nutritional quality, or occupying overwintering sites. Therefore, the less preferred food plants are usually overlooked, and their roles in the life history of hemipterans are, in general, underestimated.

Although hemipterans do not breed on these plants (at least on some of these plants), they provide nutrients, to some extent, and water, as well. However, because bugs are not used to them, sometimes they may not recognize these "host plants" as potential toxic plants, despite their polyphagy and wide capacity to overcome toxic allelochemicals or lack of essential nutrients.

Among the less preferred host plants of hemipterans, some are cultivated and some are wild, uncultivated plants. Usually, these less preferred host plants, which are used as food or shelter, are present near cultivated fields, where preferred hosts were harvested or ended their cycle and became mature. In some cases, weeds that remain green in between mature plants of a certain crop, are temporarily used as a source of nutrients and water. This situation is common in tropical or subtropical areas, where most bugs are active during the entire year (some species, however, enter diapause, underneath debris, without feeding, such as the neotropical brown stink bug, Euschistus heros (F.) [Panizzi \& Vivan 1997]).

\section{Changes in Feeding Habits}

When phytophagous hemipterans face a scarcity of preferred host plants and environmental conditions are favorable, i.e., temperature and humidity are relatively high and photoperiod is adequate, bugs will feed and remain active on less preferred plant food sources. However, they may be forced to change the feeding habits they use on preferred host plants. This may happen for several reasons: the less preferred plants possess seeds or fruits the bugs are not used to feed on; the less preferred plants may be at the vegetative stage and, although producing suitable seeds and fruits, these are not present at that moment; or the less preferred plants available may produce fruits and seeds suitable but inaccessible (out of reach - like seeds protected by thick pod walls, or by an empty space between the pod walls and the seeds). Faced with one or more of these conditions or otherelse, bugs will need to change their feeding habits and feed on other plant structures, usually not explored as food sources.

To illustrate this, I will present some examples using the southern green stink bug $N$. viridula (Pentatomidae) as a case study. Some other cases will be mentioned in less detail, including other species of pentatomid and one species of alydid, common in Northern Paraná state.

\section{Local Populations with Specific Feeding Habits}

Despite being polyphagous, but showing preferences for certain plant taxa, phytophagous hemipterans may restrict their diet, and actually act as olygophages, depending upon food availability and time of exposure to restricted hosts (see Fox \& Morrow 1981 for further discussion of feeding specialization as a species property and/or local phenomenon).

Several species of hemipterans are referred in the literature as feeding and breeding in one plant species in a certain place, and not feeding, or feeding but not reproducing, on the same host plant in another place (see several examples in Panizzi 1997). This phenomenon seems to be more common than usually thought, and adds more complication to the interactions of polyphagous bugs and the role of their host plants in their life history. Therefore, it seems reasonable to make statements based on bug vs. host plants on a local basis, and not to try to generalize results as 
being "globally true".

It is known that the same insect and plant species will be influenced by a variable environment, which will make their interactions also variable, not counting the genetic plasticity of both organisms. This dynamic coexistence over ecological time, makes the bugs and their interactions with host plants an endless game. Therefore, studies on host plant sequences and their impact to the bug's biology should be considered locally.

\section{The Polyphagous Nezara viridula (L.) as a Case Study}

The polyphagous southern green stink bug, $N$. viridula, is reported to feed on over 100 plant species in more than 30 families; because of its worldwide distribution, several host plant sequences are utilized by this bug, including some less preferred plants (references in Panizzi 1997). In Northern Paraná state, host plant sequences utilized by $N$. viridula have been characterized, including plants which are used as sources of nutrients and water, but not of reproduction (Fig. 1).

During summer and early autumn $N$. viridula concentrates on its preferred host, soybean, where it completes three generations. It moves to other suitable legumes during autumn where a 4th generation is completed. During the mild "winter" it completes a 5th generation on wild brassicas - brassicas are the second preferred taxon of this bug; a 6 th and last generation is completed on siberian motherwort, Leonurus sibiricus L. (Labiatae), a common weed plant, which is used only occasionally, before the bug starts colonizing soybean again.

In Northern Paraná, $N$. viridula will feed on less preferred host plants, which are used as sources of nutrients and/or shelter. Nymph mortality on these host plants is high in the laboratory (in the field nymphs may not even feed on these plants), and adults will not reproduce on them, and their longevity is reduced (Panizzi 1997).

\section{Feeding on Castor Bean}

Castor bean, $R$. communis (Euphorbiaceae), is a wild perennial plant very common in several parts of the world. In Northern Paraná state it grows in abandoned areas, roadsides, etc., being very abundant. Adult $N$. viridula may be captured on this plant throughout the year (Fig. 1). Adults show an atypical feeding behavior by feeding on leaf veins of this plant, and, sometimes, on immature fruits. Eggs are not laid by females on castor bean leaves, unless accidentally. During winter and fall, adults and late instars may be found aggregated on leaves, showing basking behavior (Fig. 2A). These late instars, did not develop on castor bean, but developed on other more suitable hosts, and moved to castor bean leaves to bask.

While on castor bean, adults are less susceptible to parasitization by tachinid flies than when on other host plants (Panizzi 1989). Perhaps, flies that follow the bugs on their host plants, will not visit castor bean so often, looking for $N$. viridula, because numbers of bugs on this plant are relatively low or because the plant may have chemical or physical traits that will repel the flies.

\section{Feeding on Star Bristle}

Another less preferred plant food source of $N$. viridula is the weed, star bristle, Acanthospermum hispidum DC. (Compositae). This is a common weed in soybean fields in Northern Paraná as well as in more Northern soybean production areas of Brazil.

$N$. viridula is commonly found feeding on star bristle during the late soybean season, and particularly after soybean harvest during autumn (Fig. 1). Although a seed sucker, the bug strongly prefers to feed on stems of this plant (Fig. 2B). The stems are mostly filled with an aqueous tissue and the insects apparently can detect this abundant source of water.

On several occasions, dead adults of $N$. viridula were found on the ground near the plant stem, indicating that the bugs were probably feeding on the stem and died. Labora- 


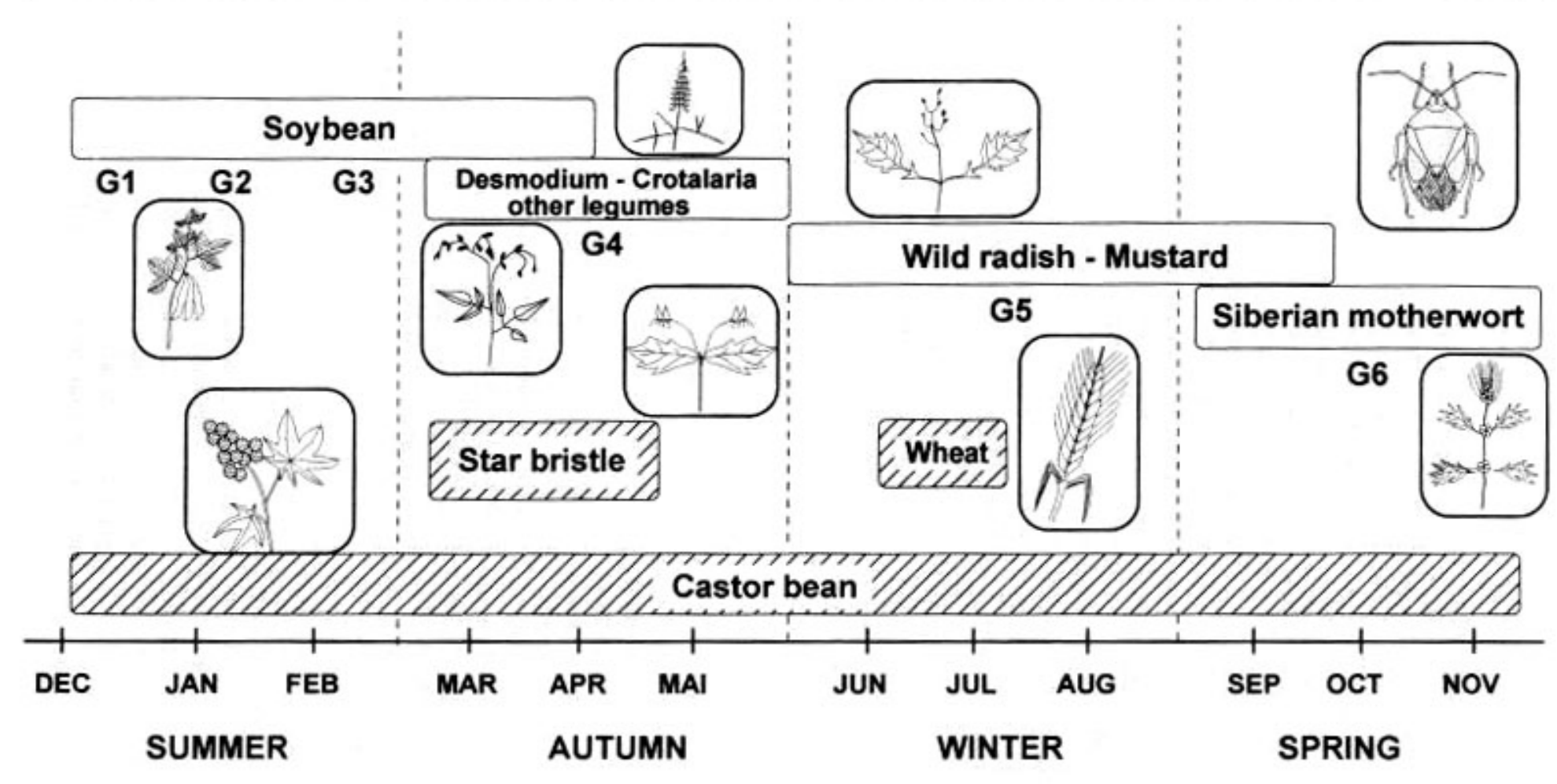

$$
\mathrm{G}=\mathrm{GENERATION}
$$

\section{REPRODUCTION}

NO REPRODUCTION

Figure 1. Host-plant sequences utilized by $N$. viridula in Northern Paraná, including preferred host (such as soybean on which plants most generations are completed) and less preferred food sources (such as star bristle, wheat and castor bean) on which plants it feeds but does not reproduce (source: Panizzi 1997). 

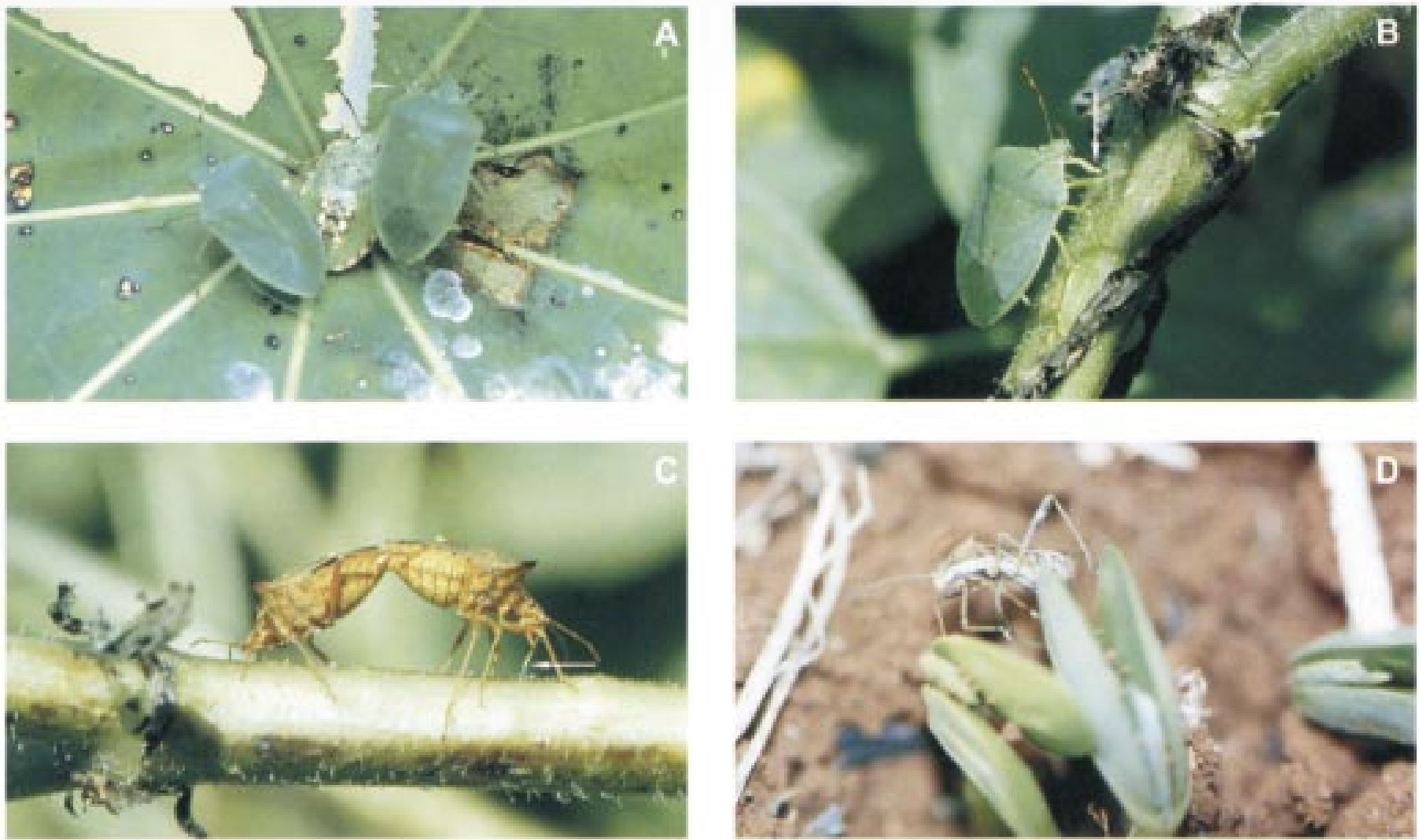

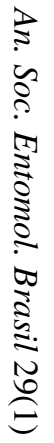

Figure 2. Different behaviors of hemipterans on less preferred plant food sources. A = Late instars and adult $N$. viridula aggregated on castor bean leaf, showing basking behavior. $\mathrm{B}=N$. viridula, a typical seed/fruit feeder, feeding on star bristle stem (arrow indicates where the stylets are introduced in the stem). $\mathrm{C}=$ a pair of E. heros, a seed sucker, in copula and feeding on star bristle stem (arrow indicates where the stylets are introduced in the stem by the female). $\mathrm{D}=$ a male of the alydid $N$. parvus, specialized to feed on mature seeds, feeding on a seedling soybean plant. 
tory studies indicated that this plant can be toxic to $N$. viridula, drastically reducing its longevity (Panizzi \& Rossi 1991) (Table 1). plants. There are reports of its damage to wheat in Brazil (Maia 1973), and to wheat and corn in the United States (Viator et al.

Table 1. Nymph and adult performance of $N$. viridula on less preferred plant food sources compared with its performance on a preferred food plant, soybean (source: references in Panizzi 1997, and A.R. Panizzi, unpublished).

\begin{tabular}{lcccc}
\hline Food source $^{1}$ & $\begin{array}{c}\text { Development } \\
\text { time (days) }\end{array}$ & Mortality (\%) & Longevity (days) & $\begin{array}{c}\text { Fecundity } \\
\text { (eggs/female) }\end{array}$ \\
\hline $\begin{array}{l}\text { Less preferred food sources } \\
\text { Acanthospermum hispidum }\end{array}$ & - & 100.0 & $6.1-7.8$ & 0.0 \\
$\begin{array}{l}\text { Albizia julibrissim } \\
\text { Crotalaria lanceolata }\end{array}$ & $27.2-33.9$ & 85.0 & $32.1-35.3$ & - \\
Croton glandulosus & 43.5 & 80.0 & - & - \\
Desmodium canum & - & 100.0 & - & - \\
$\begin{array}{l}\text { Indigofera hirsuta } \\
\text { Lepidium virginicum }\end{array}$ & - & 100.0 & - & - \\
Prunus serotina & - & 100.0 & - & - \\
Ricinus communis & $42.3-42.6$ & $60.2-86.5$ & $16.1-24.9$ & $0.0-95.0$ \\
Sesbania aculeata & - & 100.0 & - & - \\
Sesbania vesicaria & - & 100.0 & $20.0-20.3$ & 40.0 \\
Trifolium repens & 64.0 & 98.4 & - & 0.0 \\
Triticum aestivum & - & 100.0 & - & - \\
& & & & \\
Preferred food source & $22.9-32.8$ & $2.0-60.0$ & $36.5-65.0$ & $99.3-203.7$ \\
Glycine max & & & & \\
\hline
\end{tabular}

${ }^{1}$ Food sources are seeds/fruits or fruiting plants.

${ }^{2}$ From second stadium to adult.

\section{Feeding on Wheat}

Wheat, Triticum aestivum L. (Gramineae), is largely cultivated in Southern Brazil, during winter after the soybean harvest. In some years and in some areas, $N$. viridula adults have been observed feeding on reproductive plants during winter (Fig. 1). Adults will feed on seedheads, but will not lay eggs on plants. Attempts to raise nymphs in the laboratory using seedheads or mature seeds did not succeed.

$N$. viridula, although extremely polyphagous, is known not to breed on graminaceous
1983, Negron \& Riley 1987). However, this may be the case of local populations with specific feeding habits, as previously discussed. In Northern Paraná state, $N$. viridula may eventually feed on corn, but not on corn ears, rather on stems of seedling corn, grown under a no-tillage cultivation system. Bugs that stay in areas with weed plants or with scattered cultivated host plants, will eventually feed on corn seedlings that are established in these areas. However, these events are uncommon (A.R. Panizzi, unpublished).

In Table 1, some examples of nymphal and adult performances of $N$. viridula on less pre- 
ferred plant food sources are compared with its performance on a preferred plant (soybean), based on my own work and on data from the literature. Note that on most of the less preferred plants, nymphal mortality is $100 \%$ or greater than $80 \%$, whereas on the preferred host (soybean) these values are usually less than $30 \%$, reaching $60 \%$ in one case (range 2.0-60.0\%). Nymphal developmental time on less preferred plants usually lasted longer (27.2 to 64.0 days), whereas on soybean these values ranged 22.9-32.8 days. Adult longevity was drastically reduced on some of the less preferred plants, being usually less than 20 days, whereas on soybean longevity was 36.5 days and greater. Adult fecundity was also low (<40 eggs) and mostly zero on less preferred plants, whereas on soybean it ranged 99.3-203.7 eggs/female.

\section{Alterations on Food Habits of other Hemipterans}

Other species of hemipterans, like $N$. viridula, will also feed on less preferred food plants. For instance, the neotropical brown stink bug, E. heros, which is a typical seed sucker, will feed on star bristle stems (Fig. 2C). The bugs do not reproduce on star bristle, which is used only as a source of water and some nutrients. Unlike $N$. viridula, this bug seems not to become intoxicated when feeding on this plant (Panizzi \& Rossi 1991).

Another pentatomid, Dichelops melacanthus (Dallas), previously reported as a pest of soybean, and feeding on pods (Galileo et al. 1977), has been observed to feed on corn, Zea mays L., and on wheat. It is interesting that on these two graminaceous plants, the bugs feed on the stems of young plants, causing substantial damage. This change in feeding habits, from reproductive structures of more preferred hosts, such as legumes (soybean), to vegetative tissues of less preferred hosts (graminaceous), is attributed to the low availability of preferred hosts. After soybean harvest, D. melacanthus stays on the ground underneath debris, and will feed on corn or wheat plants growing in areas under conservation tillage. In these areas, bugs find shelter (straw) and food (dried seeds fallen to the ground) and will thrive. This differs from what occurs in areas under conventional cultivation systems, where bugs are dislodged from their shelters and killed due to plowing.

A similar situation occurs with the alydid Neomegalotomus parvus (Westwood). This is a typical seed sucker which feeds on mature seeds of legumes. In areas under conservation tillage, this bugs will feed on soybean seedlings (Fig. 2D). In areas under conservation tillage, they stay on the ground feeding on their preferred food (mature seeds) and will complement their diet by feeding on a less preferred food source, i.e., young plants (Panizzi \& Chocorosqui 1999).

\section{Concluding Remarks}

In the life history of phytophagous hemipterans, the less preferred plant food sources play an important role. Because bugs are in general polyphagous, food plants are often assumed to be equally suitable to the bug's biology, which is certainly not true. Moreover, some plants on which they feed are used only on special occasions or during limited times, and have very low nutritional value, although having their specific functions.

And here comes the question: What really is a host plant? A plant on which the bugs commonly feed and develop but do not reproduce - is it a host plant? And a plant on which the bugs eventually feed, but do not develop and do not reproduce - is it a host plant? Or, a plant on which the bugs do not feed, develop or reproduce, but rather use as shelter - is it a host plant? It seems that the definition of what usually characterize a host plant, i.e., a plant on which an insect usually develops and reproduces, can not be restricted, but, rather, must be flexible. Independently of what is or will come to be the ultimate definition of a host plant, the less preferred plant food sources, considered host plants or not, are essential links in the intricate net that is the life history of hemipterans. Many aspects of the biology of 
hemipterans have been investigated, some in great detail, some in less detail, and some in even less detail. Perhaps one of the aspects least studied is this subject of less preferred plant food sources. If we are, for example, to develop holistic integrated pest management systems, more attention should be devoted to this issue. If we are, for example, to develop predicting population outbreak models, this issue should be considered. If we are, for example, to develop a host-plant-sequence model, this issue should be considered. And so on and on. Although generally considered a minor component of the entire life history of bugs, the less preferred plants may hold "secrets" of great value. Once revealed, they may be the key to fully understanding the biology of hemipterans.

\section{Acknowledgments}

I thank the editor, Sueli S. Martinez, for inviting me to write this paper. Discussions about this topic with Carl W. Schaefer were very productive and are appreciated. I also thank C. W. Schaefer, Maurício U. Ventura, and Daniel R. Sosa Gomez for their useful comments on an early draft of the manuscript. This is a contribution of Embrapa Soja, number 03/2000, published with the approval of the technical director.

\section{Literature Cited}

Becker, M. 1996. Uma nova espécie de percevejo-castanho (Heteroptera: Cydnidae: Scaptocorinae) praga de pastagens do centro-oeste do Brasil. An. Soc. Entomol. Brasil 25: 95-102.

Bowling, C.C. 1979. The stylet sheath as an indicator of feeding activity of the rice stink bug. J. Econ. Entomol. 72: 259-260.

Bowling, C.C. 1980. The stylet sheath as an indicator of feeding activity by the southern green stink bug on soybeans. J. Econ. Entomol. 73: 1-3.

Fox, L.R. \& P.A. Morrow. 1981. Spe- cialization: species property or local phenomenon? Science 211: 887-893.

Galileo, M.H.M. \& E.A. Heinrichs. 1979. Danos causados à soja em diferentes níveis e épocas de infestação durante o crescimento. Pesq. Agropec. Bras. 14: 279-282.

Galileo, M.H.M, H.A.O. Gastal \& J. Grazia. 1977. Levantamento populacional de Pentatomidae (Hemiptera) em cultura de soja (Glycine max (L.) Merr.) no município de Guaíba, Rio Grande do Sul. Rev. Bras. Biol. 37: 111-120.

Goodchild, A.J.P. 1966. Evolution of the alimentary canal in Hemiptera. Biol. Rev. 41: 97-140.

Heliövaara, K. Economic importance of Aradidae. In C.W. Schaefer \& A.R. Panizzi (eds.). Heteroptera of economic importance. Boca Raton, CRC Press, in press.

Hori, K. Possible causes of disease symptom resulting from the feeding of phytophagous Heteroptera. In C.W. Schaefer \& A.R. Panizzi (eds.). Heteroptera of economic importance. Boca Raton, CRC Press, in press.

Lis, J.A., M. Becker \& C.W. Schaefer. Economic importance of Cydnidae. In C.W. Schaefer \& A.R. Panizzi (eds.). Heteroptera of economic importance. Boca Raton, CRC Press, in press.

Maia, N.G. 1973. Ocorrência do percevejo da soja-Nezara viridula (L.) em espigas de trigo no Rio Grande do Sul.. Agron. Sulriogr. 9: 241-243.

Miles, P. W. 1972. The saliva of Hemiptera. Adv. Insect Physiol. 9: 183-255.

Nault, L.R. \& G.G. Gyrisco. 1966. Relation of the feeding process of the pea aphid to the inoculation of pea enation mosaic virus. Ann. Entomol. Soc. Am. 59: 1185- 
1197.

Negron, J.F. \& T.J. Riley. 1987. Southern green stink bug, Nezara viridula (Heteroptera: Pentatomidae), feeding in corn. J. Econ. Entomol. 80: 666-669.

Panizzi, A.R. 1989. Parasitismo de Eutrichopodopsis nitens (Diptera: Tachinidae) em Nezara viridula (L.) (Hemiptera: Pentatomidae) observado em distintas plantas hospedeiras. Pesq. Agropec. Bras. 24: 1555-1558.

Panizzi, A.R. 1997. Wild hosts of pentatomids: ecological significance and role in their pest status on crops. Annu. Rev. Entomol. 42: 99-122.

Panizzi, A.R. \& V.R. Chocorosqui. 1999. Pragas. Eles vieram com tudo. Cultivar 11: 8-10.

Panizzi, A.R. \& J. Grazia. Stink bugs (Pentatomidae) and a unique host plant in the Brazilian subtropics. Iheringia (in press).

Panizzi, A. R. \& E. Machado-Neto. 1992. Development of nymphs and feeding habits of nymphal and adult Edessa meditabunda (Heteroptera: Pentatomidae) on soybean and sunflower. Ann. Entomol. Soc. Amer. 85: 477-481.

Panizzi, A.R., J.E. McPherson, D.G. James, M. Javahery \& R.M. McPherson. Economic importance of stink bugs (Pentatomidae). In C.W. Schaefer \& A.R. Panizzi (eds.). Heteroptera of economic importance. Boca Raton, CRC Press, in press.

Panizzi, A. R. \& C. E. Rossi. 1991. The role of Acanthospermum hispidum in the phenology of Euschistus heros and of Nezara viridula. Entomol. Exp. Appl. 59: 67-74.
Panizzi, A. R. \& L. M. Vivan. 1997. Seasonal abundance of the neotropical brown stink bug, Euschistus heros in overwintering sites and the breaking of dormancy. Entomol. Exp. Appl. 82: 213217.

Rizzo, H.F.E. 1971. Aspectos morfologicos y biologicos de Edessa meditabunda (F.) (Hemiptera, Pentatomidae). Rev. Per. Entomol. 14: 272-281.

Rizzo, H.F.E. 1976. Hemípteros de interés agrícola. Buenos Aires, Argentina, Editorial Hemisferio Sur, 69 pp.

Schuh, R.T. \& J.A. Slater. 1995. True bugs of the world (Hemiptera: Heteroptera). Classification and natural history. Ithaca, Cornell University Press, 336 pp.

Shorland, F.B. 1963. The distribution of fatty acids in plant lipids, p. 253-312. In T. W. Swain (ed.). Chemical plant taxonomy, London, Academic Press, 543 p.

Silva, A. G. D.'A., C. R. Gonçalves, D. M. Galvão, A. J. L. Gonçalves, J. Gomes, M. N. Silva \& L. Simoni. 1968. Quarto catálogo dos insetos que vivem nas plantas do Brasil - seus parasitas e predadores. Min. Agric., Rio de Janeiro, Parte II, vol. I, 622 p.

Simpson, S.J. \& C.L. Simpson. 1990. The mechanisms of nutritional compensation by phytophagous insects, p. 111-160. In E.A. Bernays (ed.). Insect-plant interactions. Volume II. Boca Raton, CRC Press, 199 p.

Slansky Jr., F. \& A.R. Panizzi. 1987. Nutritional ecology of seed-sucking insects, p. 283-320. In F. Slansky, Jr. \& J.G. Rodriguez (eds.). Nutritional ecology of insects, mites, spiders and related invertebrates. New York, Wiley, 1066 p. 
Slansky Jr., F. \& J.M. Scriber. 1985. Food consumption and utilization, p. 87-163. In G.A. Kerkut \& L. I. Gilbert (eds.). Comprehensive insect physiology, biochemistry and pharmacology. Vol. 4. Regulation, digestion, nutrition, excretion. Oxford, U.K., Pergamon Press, $639 \mathrm{p}$.

Todd, J.W. \& D.C. Herzog. 1980. Sampling phytophagous Pentatomidae on soybean, p. 438-478. In M. Kogan and D. C. Herzog (eds.), Sampling methods in soybean entomology. New York,
Springer-Verlag, 587 p.

Viator, H.P., A. Pantoja \& C.M. Smith. 1983. Damage to wheat seed quality and yield by the rice stink bug and southern green stink bug (Hemiptera: Pentatomidae). J. Econ. Entomol. 76: 14101413.

Zucchi, R.A., S. Silveira Neto \& O. Nakano. 1993. Guia de identificação de pragas agrícolas. FEALQ, Piracicaba, SP, $139 \mathrm{p}$. 